\title{
Response of Jute Mallow (Corchorus olitorius L.) to organic manure and inorganic fertilizer on a ferruginous soil in North-eastern Benin
}

\author{
TOVIHOUDJI G. Pierre1, DJOGBENOU C. Paul2, AKPONIKPE P.B. Irénikatché1, KPADONOU Esaïe 1, \\ AGBANGBA C. Emile $283^{*}$, DAGBENONBAKIN D. Gustave ${ }^{2}$ \\ ${ }^{1}$ Environmental Soil Physics and Hydraulics Unit (ESPH), Faculty of d'Agronomy (FA), University of Parakou (UP), 03 \\ BP 351 Parakou, Benin. \\ ${ }^{2}$ National Institute of Agricultural Research of Benin, INRAB. Postal Code: 01 BP 884. \\ ${ }^{3}$ Department of Plant Biology, University Cheikh Anta Diop of Dakar, B.P 5005, Senegal. \\ ${ }^{*}$ Corresponding author email: agbaemile@yahoo.fr
}

Original submitted in on 28 $28^{\text {th }}$ May 2015. Published online at www.m.elewa.org on $31^{\text {st }}$ August 2015 http://dx.doi.org/10.4314/jab.v92i1.5

\begin{abstract}
Objective: The study aimed to evaluate the effects of three types of fertilizers (Municipal solids waste compost, cow dung and chemical fertilizer) on growth characters and leaf yield of Corchorus olitorius under irrigated conditions

Methodology and results: A field experiment was conducted in Parakou in the dry season using a randomized complete block design with three factors and twelve treatments: 1) Municipal solids waste Compost (MSWC) at 0, 10, 20 and 30 t.ha-1 $^{-1}$;) Cow dung at 0, 10, 20 and 30 tha- $^{-1}$; Urea fertilizer $(46 \% \mathrm{~N})$ at 0, 50, 100 and 200 $\mathrm{kg} \cdot \mathrm{ha}^{-1}$. The plant height and stem diameter were significantly higher with Compost ( $\left.20 \mathrm{t} / \mathrm{ha}\right)$ and lowest was recorded in control at all growth stages. The application of compost, cow dung and chemical fertilizer significantly increased the total number of branches at all growth stages. The highest number was recorded in MSWC 20 t.ha-1 $^{-1}$ as compared to the other treatments. The highest marketable leaves yield was obtained with MSWC at 20 t.ha $^{-1}\left(8.1\right.$ t.ha $\left.^{-1}\right)$ followed by MSWC at 30 t.ha $^{-1}\left(6.6\right.$ t.ha-1 $\left.^{-1}\right)$, cow dung at 30 t.ha-1 $(5.4$ t.ha-1) and urea at $100 \mathrm{~kg}^{-h^{-1}}\left(5.4 \mathrm{t}^{-} \mathrm{ha}^{-1}\right)$, while control recorded lower values. A significant quadratic response on fresh leaf yield was observed with MSWC leading to a maximum of yield of 8.15 tha-1 $^{-1}$ at 23.03 t.ha-1 $^{-1}$.

Conclusion and application of results: The results indicated that the MSWC performs better when used at the optimal rate (23.03 tha-1), and can be used as a promising fertilizer source in Corchorus olitorius production in Benin.
\end{abstract}

Key words: Leaf yield, waste compost, cow dung, Corchorus olitorius, Benin

\section{INTRODUCTION}

Jute Mallow (Corchorus olitorius) is a popular and leafy vegetable of great importance in Benin (Dansi et al., 2008, 2009). It is an erect annual herb that varies from $60 \mathrm{~cm}$ to approximately $150 \mathrm{~cm}$ in height depending on the cultivar. It grows in fields next to the houses, on the market garden sites and home 

and inorganic fertilizer on a ferruginous soil in North-eastern Benin.

gardens around the world. Jute mallow plays an important role in nutrition and household food security. The leaves contain an average of $15 \%$ dry matter, $4.8 \mathrm{~g}$ of protein, $259 \mathrm{mg}$ of calcium, $4.5 \mathrm{mg}$ of iron, $4.7 \mathrm{mg}$ of vitamin $\mathrm{A}, 92 \mu \mathrm{g}$ of folates, $1.5 \mathrm{mg}$ of nicotinamide and $105 \mathrm{mg}$ of ascorbic acid per $100 \mathrm{~g}$ of leaves (Grubben and Denton, 2004; Harborne et al., 1999). Despite its nutritional and economic importance, it has been neglected by scientific research and development in Benin. However, there is also a growing international recognition that Neglected and Underutilized Species (NUS) play a role in providing food and nutrition security and income opportunities among smallholder farmers. These NUS crops, trees and animals can help in adapting agriculture and food systems to climate change. Many farmers, especially in marginal areas, rely on NUS for their livelihoods. Consequently, cultivated varieties run the risk of genetic erosion and their cultivation is in serious decline due to low fertility soil, poor yield, pest and diseases. In traditional farming systems, low quantity of fertilizer is applied (Ayodélé et al., 2006). In addition, these systems benefit from only the natural soil fertility and possibly small amounts of fertilizer applied to increase the production of other associated crops. This residual fertility is insufficient to meet the crop nutrient supply. Therefore adequate fertilization is essential to maximize their yields. Indeed, jute mallow requires nutrients such as $\mathrm{N}, \mathrm{P}, \mathrm{K}, \mathrm{Mg}, \mathrm{Ca}$, $\mathrm{Na}$ and $\mathrm{S}$ for a good yielding. These nutrients are specific in function and must be supplied to the plant at the right time and in the right quantity. Jute mallow responds well to fertilization, particularly nitrogen (Ogunrindé and Fasinmirin, 2011). Moreover, this

\section{MATERIAL AND METHODS \\ Material}

Site location and climate: Experiments were conducted in the dry season (from December 2012 to February 2013), at the Teaching and Research Farm of Faculty of Agricultural Sciences, University of Parakou in northern Benin with $09^{\circ} 20^{\prime} 16.8^{\prime \prime}$ as latitude North; $002^{\circ} 38^{\prime} 54^{\prime \prime}$ as longitude East and $353 \mathrm{~m}$ as altitude (Figure 1). The climate is tropical soudanian, characterized by an average of $800-1100 \mathrm{~mm}$ of annual rainfall and $24-31$ ${ }^{\circ} \mathrm{C}$ monthly temperature. The rainy season extends from May to October. The average relative humidity is $18-$ crop is mostly carried out by marginalized producers of whom access to mineral fertilizers is prohibitive because of their low income (Gensch et al., 2011). Besides, excessive and indiscriminate use of chemical fertilizers leads to soil degradation and imposes a serious threat to human health (Fujimoto, 1998). Also, jute mallow is cultivated on a small scale by women only, so that the production cannot pay back the cost of purchase and transportation of mineral fertilizers. All the above reasons underscore the acute need of alternative sources of fertilizer for sustainable crop production. Organic waste could be a viable alternative to chemical fertilizers. The use of organic manure, e.g. municipal waste compost and cow dung has improved agricultural productivity in West African countries. Organic farming has enough positive impacts: the long-term productivity in soil conservation and improvement of soil fertility involves the sustainability of production for future generations, stability and food security in diversity cultures and environmental impact using manure. Indeed, organic manures enhance soil moisture, increased soil organic matter, nitrogen, $\mathrm{pH}$, phosphorus, and cation exchange capacity (CEC), and reduced soil exchangeable acidity (Ngeze, 1998; Adeniyan and Ojeniyi, 2003; Mbah, 2006; Ayeni et al., 2008; Alabadan et al., 2009; Adeleye et al., 2010; Dikinya and Mufwanzala, 2010; Njoku and Mbah, 2012; Adejuyigbe et al., 2012; Darzi and Haj Seyd Hadi, 2012; Najm et al., 2012). The present paper aims to determine the rate of compost/cow dung application that produces the highest yield of Corchorus olitorius compared to the urea rate under North-eastern Benin conditions.

$99 \%$. Initial soil characteristics and chemical properties of compost and cow dung: Five fractions of soil texture were determined using the international method modified by the use of Robinson pipette. The organic carbon by Walkey and Black method, the total nitrogen by Kjeldahl method, the $\mathrm{pH}$ (1/2.5 ratio soil-water), the phosphorus according to Bray 1 method, the exchangeable cations by the acetate of ammonium method. Calcium and magnesium were measured by titration with EDTA and the potassium was determined with a flame photometer. 


\section{Tovihoudji et al. J. Appl. Biosci. Response of Jute Mallow (Corchorus olitorius L.) to organic manure and inorganic fertilizer on a ferruginous soil in North-eastern Benin.}

The soil is tropical ferruginous very much leached and poor. The texture found in the top $20 \mathrm{~cm}$ was clay loamy with $35 \%$ of clay, $43 \%$ of loam and $22 \%$ of sand. Organic matter (OM) and total nitrogen contents in the experimental soils were $0.6 \%$ and $0.1 \%$ respectively. On most plots, organic matter contents were low (OM $>2.5 \%)$. All sites showed neutral $(6.6<\mathrm{pH}<7.3)$ soils $\mathrm{pH}$. The $\mathrm{C} / \mathrm{N}$ ratios ranged between 10 and 12 , indicating a good mineralization. The potassium was low $<0.15$ $\left.\mathrm{cmol}^{\mathrm{kg}}{ }^{-1}\right)$. The Cation Exchange Capacity (CEC) $(<15$ $\mathrm{cmol}^{\mathrm{kg}}{ }^{-1}$ ) was low in the sites. Available phosphorus according to Bray method was low in the top soil (table 1). In summary, soils in location had low soil fertility. Samples of composts and cow dung were air-dried and used for mineral content determination. Samples were digested with nitric-perchloric-sulphuric acid mixture at $120^{\circ} \mathrm{C}$ during 3 hours in a Teflon digester. Digested samples were thereafter diluted with distilled water. Total $\mathrm{K}$ contents were measured by atomic absorption spectrophotometry using an AAS-800 spectrophotometer (Perkin Elmer, Wellesley, MA, USA). Total P content was determined by the colorimetric method using molybdovanadate reagent (Stewart et al. 1974) and total $\mathrm{N}$ content by the Kjeldahl (block digestion) method (AOAC 981.10) (AOAC, 1990). The nitrogen content ranged from $17.2 \%$ in the MSWC to 6.1 in the cow dung. The $\mathrm{pH}$ was basic (8.1) in the MSWC and weakly acid (6.0) in cow dung. Organic carbon ranged from 17 in the MSWC to $3.8 \%$ in the cow dung. $P$ was 10.3 in the MSWC and 1.4 in the cow dung. The $\mathrm{K}$ contents varied from $11.3 \%$ in the MSWC to $2.6 \%$, whereas calcium (Ca) ranged between $36.9 \%$ in the MSWC and $6.9 \%$ in the cow dung, and magnesium $(\mathrm{Mg})$ between $2.9 \%$ and 0.9 (table 1).

Table 1: Initial soil characteristics and chemical properties of compost and cow dung (CD)

\begin{tabular}{lccc}
\hline Soil parameter & MSWC & Cow dung (CD) & Soil \\
\hline Chemical characteristics & & & \\
pH & 8.1 & 6.0 & 6.7 \\
Organic C (\%) & 17 & 3.8 & 0.6 \\
Total nitrogen (\%) & 17.2 & 6.1 & 0.1 \\
Available phosphorus (\%) & 10.3 & 1.4 & 0.2 \\
Exchangeable Cations $\left(\mathrm{Cmol}^{\mathrm{k}} \mathrm{kg}^{-1}\right)$ & $\mathrm{nd}$ & $\mathrm{nd}$ & 6.4 \\
$\mathrm{Ca}(\%)$ & 36.9 & 6.9 & 0.8 \\
$\mathrm{Mg}(\%)$ & 2.9 & 0.9 & 1.2 \\
$\mathrm{~K}(\%)$ & 11.3 & 2.6 & 2.1 \\
Physical characteristics & & & \\
Sand $(\%)$ & nd & nd & 22 \\
Silt (\%) & nd & nd & 43 \\
Clay $(\%)$ & nd & nd & 35 \\
\hline
\end{tabular}

nd: not determined

Crop variety used in the Experiment: Seedlings of $C$. olitorius were hardened and transplanted at three weeks after sowing (WAS). Transplanting was carried out in the evening with seedlings transplanted at a spacing of $0.4 \mathrm{~m}$ $\mathrm{x} 0.1 \mathrm{~m}$ to give a total of 250000 plants ha-1 $^{-1}$. Plants were watered immediately after transplanting and thereafter daily until rainfall was regular.

Experimental design: The experimental design was a complete randomized block design with thrice replicated. Treatments consisted of three fertilizer types at different levels, i.e. urea (U) $46 \% \mathrm{~N}$ applied at 50, 100 and 200 $\mathrm{kg} \cdot$ ha $^{-1}$; municipal solid waste compost (MSWC) applied at 10, 20 and 30 t.ha- $^{-1}$ and cow dung (CD) at 10, 20 and 30 t.ha $^{-1}$ and the control (no fertilizer).
Field management and observations: The experimental area was divided into three blocs each containing 12 plots (to give 36 experimental units). Each plot measured $4 \mathrm{~m} \times 1.2 \mathrm{~m}$ with $0.5 \mathrm{~m}$ spacing between plots and $1 \mathrm{~m}$ apart in each block of rows for easy movement during cultural operations. The MSWC was obtained from the Parakou solid waste recycling and composting station, where it was produced under aerobic conditions and placed in windrows for final maturing. Composting took about four months; however, the compost was collected and stored before field application. The municipal waste compost and cow dung were dried and incorporated into the soil three week before seedling transplantation while urea was applied two week after transplanting (WAT). Fertilizers were applied by band 


\section{Tovihoudji et al. J. Appl. Biosci. Response of Jute Mallow (Corchorus olitorius L.) to organic manure and inorganic fertilizer on a ferruginous soil in North-eastern Benin.}

placement at $5 \mathrm{~cm}$ depth and $7 \mathrm{~cm}$ away from the plants, with proper covering up by holes to prevent nutrients leaching by run-off. Weeding was applied manually at two weeks intervals and spraying with neem extract at $20 \mathrm{ml}$ per 10 litres of water at two weeks intervals to control insects. The growth and yield parameters collected to assess the response of Corchorus to the fertilizer treatments were: plant height, number of leaves per plant, number of branches per plant, leaf area index (LAI), stem diameter (measured with a digital calliper), limb length, limb width and petiole length. For the plant growth measurements, five plants were selected randomly by leaving the border plants and tagged in each plot for recording various morphological observations at 2, 4, 6 days and week after transplanting (WAT). At Harvest (6 weeks after transplanting), six plants of each treatment were sampled and cut. Then, the plants were separated into leaves, stems and roots and weighed with a sensitive

\section{RESULTS}

Plant growth: Corchorus olitorius according to the different treatments showed a significant effect on growth parameters at 8 weeks after transplanting (Table 2). The average plant height, number of leaves, stem diameter, leaf area and number of branches increased as the levels of inorganic and organic fertilizers application increased. However, MSWC at 30 t.ha-1 $^{-1}$ cow dung (CD) at 30 t.ha-1 $^{-1}$ and urea at $200 \mathrm{~kg} \cdot \mathrm{ha}^{-1}$ showed low values for few parameters. The tallest plants were obtained from MSWC at $20 \mathrm{t} / \mathrm{ha}(72.9 \mathrm{~cm})$ which was similar to MSWC at 30 t.ha-1 $(70.5 \mathrm{~cm})$ and cow dung at 30 t.ha- $^{-1}(65.1 \mathrm{~cm})$ application. Conversely, control treatment and plants fertilized with urea (200 kg.ha-1) showed significantly lower height $(34.6-37.2 \mathrm{~cm})$ (Table 1). The plants fertilized with MSWC at 10 t.ha- $^{-1}, C D$ at 10 t.ha $^{-1}, C D$ at $20 \mathrm{tha}^{-1}$, urea at $50 \mathrm{~kg} \cdot \mathrm{ha}^{-1}$ and urea at $100 \mathrm{~kg} \cdot \mathrm{ha}^{-1}$ showed similar plant height varying from 48.5 to $57.0 \mathrm{~cm}$. The plants fertilized with MSWC at 20 t.ha-1 $^{-1}$ produced the highest number of leaves per plant (118.2). Lower number of leaves per plant was obtained with control and plants fertilized with urea at $200 \mathrm{~kg} \mathrm{ha}^{-1}$. The results showed that stem diameter was significantly influenced by treatments. Significantly higher stem diameter was observed with MSWC at 30 t.ha-1 $^{-1}(8.6 \mathrm{~mm})$, followed by MSWC at 20 tha-1 $^{-1}(8.4 \mathrm{~mm})$ which was similar to MSWC at 10 t.ha-1 $^{-1}(7.5 \mathrm{~cm})$ and $C D$ at 30 t.ha-1 $^{-1}(7.7 \mathrm{~mm})$. Whereas, lower stem diameter was recorded in control (3.9 to $4.5 \mathrm{~mm}$ ) and urea at $200 \mathrm{~kg} \cdot \mathrm{ha}^{-1}(4.3 \mathrm{~mm})$. Among scale and later oven dried at $80^{\circ} \mathrm{C}$ for $24 \mathrm{~h}$ for dry weight and leaves yield per hectare. Other parameters were obtained at harvest. Only the results at 6 weeks after transplanting were presented in this paper.

Statistical analysis: Statistical analysis was performed for different fertilizer sources across growth characters, shoot and root weight, and leaves yield and yield attributing characters. Data were subjected to analysis of variance (ANOVA) using $R \quad 2.14 .1$ software ( $R$ Development Core Team, 2011) using a randomized complete block structure with 3 replications. Means were compared using least significant difference (LSD) at $p<$ 0.05 . Quadratic and linear regression analyses were performed to model crop response to fertilizer levels. The normality (Shapiro and Wilk, 1965), the homogeneity (Snedecor and Cochran, 1956) and the independence of residuals (Durbin and Waston, 1950) were checked for model validation.

the treatments, MSWC at 20 t.ha-1 $^{-1}$ recorded significantly higher (14.6) number of branches over all other treatments, followed by MSWC at 30 tha- $^{-1}(14.1)$ which was equal to MSWC at 10 tha $^{-1}(13.3)$ and $C D$ at 30 tha $^{-1}$ (13.6) while, the control had the lower number branches (8.8 to 9.2) (Table 2). Plants fertilized with MSWC at 20 t.ha- ${ }^{-1}, C D$ at 30 t/ha and urea at $100 \mathrm{~kg}^{-h^{-1}}$ showed greater height, number of leaves, stem diameter total leaf area and number of branches than other treatment (Table 2).

Shoot and root weight: The fresh shoot weight of $C$. olitorius plants fertilized with MSWC at 20 t.ha $^{-1}(46.5 \mathrm{~g}$ per plant) differed significantly $(p<0.05)$ from plants fertilized with other treatment (Table 3 ). The highest dry shoot weight was obtained from MSWC at 20 t.ha-1 $^{-1}$ (20.6 $\mathrm{g}$ per plant) application followed by MSWC at $30 \mathrm{t}^{\mathrm{ha}} \mathrm{a}^{-1}$ (15.7 g per plant) and MSWC at 10 t.ha $^{-1}$ (11.6 g per plant) (Table 3). The fresh root weight per plant was found non-significant due to treatments. The plants treated with MSWC at 30 tha $^{-1}$ showed highest fresh root weight $\left(9.7 \mathrm{~g} \mathrm{plant}^{-1}\right)$ whereas the fresh root weight of remaining treatments was considerably similar and ranged from 2.9 to $8.3 \mathrm{~g} \mathrm{plant}^{-1}$ (Table 3). C. olitorius plants fertilized with MSWC at 20 t.ha- $^{-1}$ produced significantly higher dry root weight ( $\left.2.5 \mathrm{~g} \mathrm{plant}^{-1}\right)$, whereas values of other treatments were considerably similar and ranged from 21.4 to $2.1 \mathrm{~g} \mathrm{plant}^{-1}$. Lower dry root weight was obtained with controls (Table 3 ). 
Tovihoudji et al. J. Appl. Biosci. Response of Jute Mallow (Corchorus olitorius L.) to organic manure and inorganic fertilizer on a ferruginous soil in North-eastern Benin.

Table 2: Effect of applying municipal solid waste compost (MSWC), cow dung (CD) or urea on plant growth parameters of Corchorus olitorius at 6 week after transplanting.

\begin{tabular}{|c|c|c|c|c|c|}
\hline Levels of fertilizer & $\begin{array}{l}\text { Plant Height } \\
\text { (cm) }\end{array}$ & $\begin{array}{l}\text { Number of } \\
\text { leaves }\end{array}$ & $\begin{array}{l}\text { Stem diameter } \\
(\mathrm{mm})\end{array}$ & $\begin{array}{l}\text { Leaf area } \\
\qquad\left(\mathrm{cm}^{2}\right)\end{array}$ & $\begin{array}{c}\text { Number of } \\
\text { branches }\end{array}$ \\
\hline \multicolumn{6}{|l|}{ MSWC levels (t.ha-1) } \\
\hline 0 & $37.2 a$ & $40.1 \mathrm{a}$ & $4.2 a$ & $356.8 \mathrm{a}$ & $8.9 a$ \\
\hline 10 & $57.0 \mathrm{~b}$ & $96.9 \mathrm{~cd}$ & $7.5 \mathrm{~cd}$ & $1119.5 d$ & 13.3def \\
\hline 20 & $72.9 \mathrm{c}$ & $118.2 d$ & $8.4 \mathrm{~d}$ & $1157.5 \mathrm{~d}$ & $14.6 f$ \\
\hline 30 & $70.5 \mathrm{c}$ & $107.3 d$ & $8.6 \mathrm{~d}$ & $810.0 \mathrm{bcd}$ & 14.1ef \\
\hline \multicolumn{6}{|l|}{ Cow dung levels (t.ha-1) } \\
\hline 0 & $37.2 a$ & $40.1 a$ & $4.2 a$ & $356.8 \mathrm{a}$ & $8.9 a$ \\
\hline 10 & $48.5 b$ & $55.1 a b$ & $6.1 \mathrm{~b}$ & $623.9 a b c$ & $11.7 \mathrm{~cd}$ \\
\hline 20 & $50.9 b$ & 61.1ab & $6.2 b$ & 436.6ab & $11.8 \mathrm{~cd}$ \\
\hline 30 & $65.1 \mathrm{c}$ & $91.2 \mathrm{~cd}$ & $7.7 \mathrm{~cd}$ & $905.2 \mathrm{~cd}$ & 13.6def \\
\hline \multicolumn{6}{|l|}{ Urea $\left(46 \%, \mathrm{~kg} \cdot \mathrm{ha}^{-1}\right)$} \\
\hline 0 & $37.2 a$ & $40.1 \mathrm{a}$ & $4.2 \mathrm{a}$ & $356.8 a$ & $8.9 a$ \\
\hline 50 & $50.3 b$ & $52.7 a b$ & $6.8 \mathrm{bc}$ & $616.0 \mathrm{abc}$ & $11.1 b c$ \\
\hline 100 & $53.5 b$ & $75.3 \mathrm{bc}$ & $7.1 \mathrm{bc}$ & $690.3 a b c$ & $12.5 \mathrm{cde}$ \\
\hline 200 & $37.1 \mathrm{a}$ & $43.7 a$ & $4.3 a$ & $354.9 a$ & $9.8 a b$ \\
\hline Significance & *** & $\star * \star *$ & $* \star *$ & $* * *$ & *** \\
\hline
\end{tabular}

Means with different letters within columns are significantly different at $\left.\left.5 \%{ }^{*}\right), 1 \%{ }^{* *}\right)$ and $0.1 \%{ }^{* * *}$ levels of probability respectively using the Least Significant Difference (LSD), $n=15$.

Table 3: Effect of applying municipal solid waste compost (MSWC), cow dung (CD) or urea on shoot and root characters of Corchorus olitorius at 6 week after transplanting.

\begin{tabular}{|c|c|c|c|c|}
\hline Levels of fertilizer & $\begin{array}{l}\text { Fresh shoot weight } \\
\left.\text { (g plant }{ }^{-1}\right)\end{array}$ & $\begin{array}{l}\text { Dry shoot weight } \\
\left.\text { (g plant }{ }^{-1}\right)\end{array}$ & $\begin{array}{l}\text { Fresh root weight } \\
\quad\left(\mathrm{g} \mathrm{plant}^{-1}\right)\end{array}$ & $\begin{array}{l}\text { Dry root weight } \\
\left(\mathrm{g} \mathrm{plant}^{-1}\right)\end{array}$ \\
\hline \multicolumn{5}{|l|}{ MSWC (t.ha-1) } \\
\hline 0 & $9.3 a$ & $3.7 a$ & 3.3 & $1.1 \mathrm{a}$ \\
\hline 10 & $18.6 a$ & 11.6ab & 6.9 & $2.9 \mathrm{~b}$ \\
\hline 20 & $46.5 \mathrm{c}$ & $20.6 b$ & 8.3 & 2.5ab \\
\hline 30 & $26.6 \mathrm{~b}$ & $15.7 a b$ & 9.7 & $1.9 a b$ \\
\hline \multicolumn{5}{|l|}{ Cow dung (t.ha-1) } \\
\hline 0 & $9.3 a$ & $3.7 a$ & 3.3 & $1.1 \mathrm{a}$ \\
\hline 10 & $12.2 \mathrm{a}$ & $6.4 a$ & 4.3 & $1.4 a b$ \\
\hline 20 & $21.5 b$ & $5.6 a$ & 5.0 & 1.4ab \\
\hline & $22.8 \mathrm{~b}$ & 10.0ab & 6.9 & $1.7 a b$ \\
\hline \multicolumn{5}{|l|}{ Urea $(46 \%$, kg.ha-1) } \\
\hline 0 & $9.3 a$ & $3.7 a$ & 3.3 & $1.1 \mathrm{a}$ \\
\hline 50 & $13.2 a$ & $7.0 \mathrm{a}$ & 5.1 & $1.6 a b$ \\
\hline 100 & $20.7 \mathrm{~b}$ & $7.9 a$ & 5.5 & 1.1ab \\
\hline 200 & $9.8 a$ & $6.8 \mathrm{a}$ & 4.6 & 2.1ab \\
\hline Significance & * & ** & ns & * \\
\hline
\end{tabular}

n.s: non-significant; Means with different letters within columns are significantly different at $5 \%\left({ }^{*}\right), 1 \%\left(^{* *}\right)$ and $0.1 \%\left(^{* * *}\right)$ levels of probability respectively using the Least Significant Difference (LSD), $n=6$.

Marketable leaves yield, morphological traits and response to nutrient supply: Fresh Leaves and dry weight were increased by the lower level of applied MSWC and urea significantly and were increased more by the higher levels (Table 4). The fresh leaves yield recorded was highest (33.3 g.plant-1) for plants treated with MSWC at 20 t.ha $^{-1}$, followed by MSWC at 30 tha $^{-1}$ (26.5 g.plant $\left.{ }^{-1}\right), C D^{2} 30$ at tha- ${ }^{-1}\left(21.5\right.$ g.plant $\left.^{-1}\right)$ and urea at $100 \mathrm{~kg} \cdot \mathrm{ha}^{-1}$ (21.5 g.plant $\left.{ }^{-1}\right)$. C. olitorius leaves yield responded positively to the fertilizers sources and their 


\section{Tovihoudji et al. J. Appl. Biosci. Response of Jute Mallow (Corchorus olitorius L.) to organic manure and inorganic fertilizer on a ferruginous soil in North-eastern Benin.}

levels, and the highest marketable leaves yield was obtained with MSWC at 20 t.ha-1 $^{-1}\left(8.1\right.$ t.ha- $\left.^{-1}\right)$ followed by MSWC at 30 t.ha $^{-1}\left(6.6\right.$ t.ha-1 $\left.^{-1}\right)$, CD at 30 t.ha- $^{-1}\left(5.4\right.$ t.ha $\left.^{-1}\right)$ and urea at $100 \mathrm{~kg}^{-h^{-1}}\left(5.4\right.$ t.ha $\left.^{-1}\right)$, whereas the lowest marketable leaves yield were observed with control and

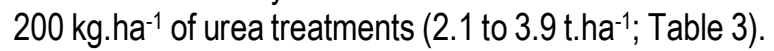
Treatment effects on leaf length, leaf width and petiole length were highly significant $(p<0.001)$. Among the treatments, 20 t.ha- $^{-1}$ of MSWC and $50 \mathrm{~kg}^{-h^{-1}}$ of urea recorded significantly higher leaf length $(9.8 \mathrm{~cm})$ followed by $30 \mathrm{t}^{\text {h ha-1 }}$ of MSWC $(9.5 \mathrm{~cm})$ and $200 \mathrm{~kg}$ of urea per ha $(9.5 \mathrm{~cm})$, while the control and $200 \mathrm{~kg}$ of urea per ha showed the minimum leaf length ranged from 4.9 to 5.6 $\mathrm{cm}$. The highest leaf width was obtained with 30 t.ha-1 $^{-1}$ of MSWC $(7.9 \mathrm{~cm})$ application followed by $100 \mathrm{~kg}$ of urea per ha $(7.8 \mathrm{~cm}), 20$ t.ha- $^{-1}$ of MSWC $(7.5 \mathrm{~cm})$ and 20 t.ha $^{-1}$ of $C D(7.1 \mathrm{~cm})$. The highest petiole length was observed from plants fertilized with 20 t.ha- $^{-1}$ of MSWC $(7.9 \mathrm{~cm})$ which was at par with MSWC 30 t.ha-1 $^{-1}(7.6 \mathrm{~cm})$ and 100 $\mathrm{Kg} \mathrm{ha}^{-1}$ of urea $(7.3 \mathrm{~cm})$ but significantly higher than other treatment (Table 4). A significant quadratic response on fresh leaf yield was observed with organic manure leading to a maximum of yield at 23.03 t.ha-1 $^{-1}$. A quadratic response on fresh leaf yield was also observed with urea but the trend was not significant (Figure 1). Linear regression was considered for $C$. olitorius yield response to cow dung levels. The application of organic material (MSWC and cow dung) at level of 20 t.ha $^{-1}$ and urea fertilizer at $100 \mathrm{~kg}^{-\mathrm{ha}^{-1}}$ to $\mathrm{C}$. olitorius plants allows obtaining higher yields.

Table 4: Effect of applying municipal solid waste compost (MSWC), cow dung (CD) or urea on leaves, marketable yield and yield components of Corchorus olitorius at 6 week after transplanting.

\begin{tabular}{|c|c|c|c|c|c|c|}
\hline Levels of fertilizer & $\begin{array}{l}\text { Fresh wt. } \\
\text { (g.plant }^{-1} \text { ) }\end{array}$ & $\begin{array}{c}\text { Dry wt. } \\
\left.\text { (g.plant }^{-1}\right)\end{array}$ & $\begin{array}{c}\text { Yield } \\
(\text { t. ha-1) }\end{array}$ & $\begin{array}{l}\text { Leaf length } \\
(\mathrm{cm})\end{array}$ & $\begin{array}{l}\text { Leaf width } \\
\text { (cm) }\end{array}$ & $\begin{array}{c}\text { Petiole } \\
\text { length }(\mathrm{cm})\end{array}$ \\
\hline \multicolumn{7}{|l|}{ MSWC (t.ha-1) } \\
\hline 0 & $11.9 \mathrm{a}$ & $3.5 \mathrm{a}$ & $3.1 \mathrm{a}$ & $5.6 a$ & $4.5 a$ & $4.0 \mathrm{a}$ \\
\hline 10 & 18.1ab & $7.5 \mathrm{bc}$ & $6.8 b$ & $8.3 b c d$ & $6.8 \mathrm{bc}$ & $6.9 \mathrm{~cd}$ \\
\hline 20 & $33.3 c$ & $8.6 \mathrm{c}$ & $8.0 \mathrm{c}$ & $9.8 d$ & $7.5 \mathrm{c}$ & $7.9 \mathrm{~d}$ \\
\hline 30 & $26.5 b c$ & $5.4 a b$ & $7.6 \mathrm{bc}$ & $9.5 \mathrm{~cd}$ & $7.9 \mathrm{c}$ & $7.6 \mathrm{~d}$ \\
\hline \multicolumn{7}{|l|}{ Cow dung (t.ha-1) } \\
\hline 0 & $11.9 a$ & $3.5 \mathrm{a}$ & $3.1 \mathrm{a}$ & $5.6 a$ & $4.5 a$ & $4.0 \mathrm{a}$ \\
\hline 10 & 13.8ab & $4.4 a$ & $3.5 a b$ & $7.8 \mathrm{~b}$ & $5.8 \mathrm{bc}$ & $5.6 \mathrm{bc}$ \\
\hline 20 & $16.5 a b$ & $4.7 a$ & 4.1ab & $8.5 b c d$ & $7.1 \mathrm{bc}$ & $6.2 \mathrm{bc}$ \\
\hline 30 & $21.5 a b c$ & $5.1 \mathrm{a}$ & $5.4 a b c$ & $8.1 b c$ & $6.9 \mathrm{bc}$ & $6.2 \mathrm{bc}$ \\
\hline \multicolumn{7}{|l|}{ Urea $(46 \%$, kg.ha-1) } \\
\hline 0 & $11.9 \mathrm{a}$ & $3.5 a$ & $3.1 \mathrm{a}$ & $5.6 a$ & $4.5 a$ & $4.0 \mathrm{a}$ \\
\hline 50 & $13.4 a b$ & $4.3 a$ & $3.4 a b$ & $9.8 d$ & $6.9 \mathrm{bc}$ & $6.2 b c$ \\
\hline 100 & $21.5 a b c$ & $5.5 a b$ & $5.4 a b c$ & $9.5 \mathrm{~cd}$ & $7.8 \mathrm{c}$ & $7.3 \mathrm{~cd}$ \\
\hline 200 & $10.6 a$ & $4.2 \mathrm{a}$ & $3.7 a$ & $5.4 a$ & $4.6 a$ & $4.7 a b$ \\
\hline Significance & $* * *$ & $* * *$ & $\star \star \star$ & $* \star * *$ & $* * *$ & $\star * *$ \\
\hline
\end{tabular}

n.s: non-significant; Means with different letters within columns are significantly different at $5 \%\left({ }^{*}\right), 1 \%\left({ }^{* *}\right)$ and $0.1 \%\left({ }^{* * *}\right)$ levels of probability respectively using the Least Significant Difference (LSD). 

and inorganic fertilizer on a ferruginous soil in North-eastern Benin.
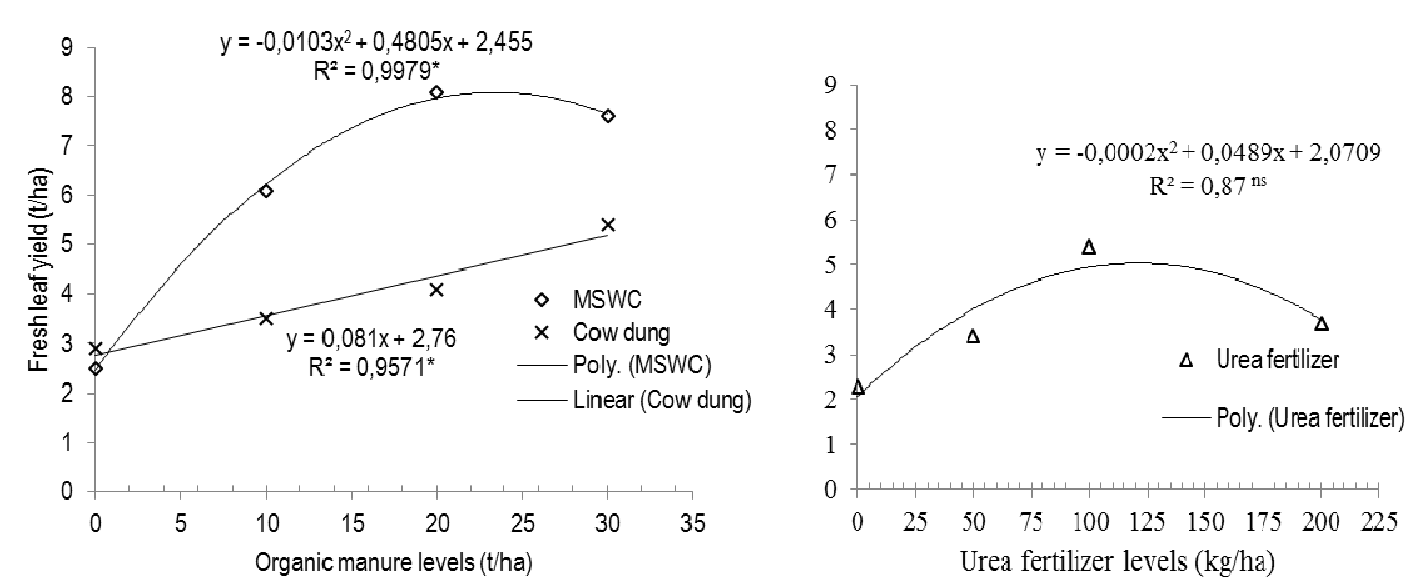

Figure1: Jute mallow yield response to organic manures and urea fertilizer levels. Measured yields (dots) are treatment average modelled by parabolic curves or linear trendlines (equation and $R^{2}$ ). $n s$ or * mean that model is not or significant at $p<0.05$ respectively.

\section{DISCUSSION}

Effect of different fertilizer types on growth parameters: The application of organic manures enhanced significantly the growth parameters (plant height, number of leaves, stem diameter, total leaf area and number of branches) in $\mathrm{C}$. olitorius. The application of 20 tons of MSWC per ha favourably influenced the different growth parameters at 6 WAT followed by 30 tons of cow dung per ha and $100 \mathrm{~kg}$ of urea per ha. Several authors mentioned similar results on different plants such as Emuh (2013) on jute mallow, Khalil and El-Sherbeny (2003) on three Mentha species plants, Khalil et al. (2002) on Tagetes erecta, El-Desuki et al. (2001) on sweet fennel, Rekha and Gopal Krishna (2001) in bitter gourd, Aliyu (2000) on pepper, Dauda et al. (2005) on eggplant, Sutagundi (2000) in chilli, Herrera et al. (1997) on horehound, thyme and angelica plants and O'Brien and Barker (1996) on peppermint, who observed that increasing organic manures levels in soil improved significantly growth characters. This has been the consequence because of higher nutrient availability and increased nitrogen from organic manures (MSWC and cow dung) which had profoundly influenced in mobilizing the nutrients from the unavailable form of nutrients mainly due to improved physical, chemical and biological properties of the soil. This increasing reconfirmed the role of nitrogen in promoting vigorous vegetative growth in leafy vegetables (Tisdale and Nelson, 1990). This showed also that nitrogen stimulates formation of new leaves and increases the size and height of plant. As well established previously in the literature, manures increase organic matter and plant nutrient availability, and improve some soil physical properties (Aliyu, 2000; Adeniyan and
Ojeniyi, 2005; Adenawoola and Adejoro, 2005; Agbede et al., 2008; Okonwu and Mensah, 2012; Emuh, 2013). The application of different rates of urea influenced plant height, stem diameter and number of leaves variably at 6 weeks after transplanting. This improvement of vegetative characteristics with the increasing of different rates of urea could be attributed to increased uptake of nitrogen and its associated role in chlorophyll synthesis and hence the process of photosynthesis and carbon dioxide assimilation (Jasso-chaverria et al., 2005) leading to enhanced growth. It was observed that, the control was not statistically different with plots that received 200 $\mathrm{Kg}$. ha- ${ }^{-1}$ of urea and for this reason, it can be deduced that the application of over $100 \mathrm{Kg} \cdot \mathrm{ha}^{-1}$ of urea fertilizer $(46 \%$ $\mathrm{N})$ does not enhance the growth of $\mathrm{C}$. olitorius. The reduced plant height, number of leaves and stem diameter on plots subjected to no fertilizer can be attributed to deficiency of nitrogen in the soil and hence stunted plants.

Effect of different types of fertilizer on leaves yield and yield parameters: Yield is the manifestation of morphological, physiological, biochemical and growth parameters and is considered as a result from the trapping and conversion of solar energy efficiency. Yield is polygenic in nature and is influenced by several factors (internal and external) throughout the crop growth period. The treatment with 20 tons per ha of MSWC recorded significantly higher yield followed by 30 tons per ha of cow dung. The reasons for increased leaves yield was due to the increased solubilization effect and availability of nutrients by the addition of organic manures (OM) that increased physiological activity leading to the build-up of 


\section{Tovihoudji et al. J. Appl. Biosci. Response of Jute Mallow (Corchorus olitorius L.) to organic manure and inorganic fertilizer on a ferruginous soil in North-eastern Benin.}

sufficient food reserves for the developing sinks and better portioning towards the developing leaves. Similar results were also reported by Emuh (2013), Okonwu and Mensahin (2012) and Arancon et al. (2006). As this study showed, plants seem to perform better in treatments receiving compost due to the presence of growth promoting substances (Sridevi and Srinivasamurthy, 2010), micro-nutrients, and a variety of inorganic and organic compounds. At the same time, addition of organic amendments improves soil structure, aggregate stability and moisture retention capacity (Bhattacharyya et al., 2008). Moreover, in this study, higher fresh shoot weight was observed with plants fertilized with 20 tons per ha of MSWC compared to plants fertilized with various levels of cow dung or urea. In contrast, there is no significant difference between different treatments for fresh root weight. Plants adjust themselves to nutrient uptake and absorption via profuse growth of roots. Similarly, the results may in part be explained by the increased

\section{CONCLUSION}

Under Northern Benin environmental conditions, the different types and dose of fertilizer positively affects growth parameters and yield of $C$. olitorious. The municipal solids waste compost (MSWC) performs better

\section{ACKNOWLEDGEMENT}

This study was sponsored by the Municipality of Parakou through the Faculty of Agronomy of the University of Parakou. We gratefully acknowledge the valuable technical assistance of Landry Ahoga an extension

\section{REFERENCES}

Adejuyigbe C.O., Adesodun J. K., Harris P. J.C., Aiyelaagbe I.O.O., 2012. Potential of on-farm produced compost and organic amendments in soil fertility management for organic maize production in south western Nigeria. Archives of Agronomy and Soil Science, 58 (1): 170-174.

Adeleye E.O, Ayeni L.S., Ojeniyi S. O., 2010. Effect of poultry manure on soil physico-chemical properties, leaf nutrient contents and yield of yam (Dioscorea rotundata) on alfisol in south western Nigeria. J. Am. Sci., 6(10): 956-959.

Adenawoola A.R. and Adejoro S.A., 2005. Residual effects of poultry manure and NPK Fertilizer residues on soil nutrient and performance of Jute (Corchorus olitorius L.). Nigerian Journal of Soil Science, 15: 133-135.

Adeniyan O.N. and Ojeniyi S.O., 2003. Comparative effectiveness of different levels of poultry microbial activities and release of phytohormones and enzymes with compost application. The results of this study revealed that the application of urea $(46 \% \mathrm{~N})$ increases fresh and dry leaves yield of jute mallow to a point where further increase in fertilizer results into a decline in productivity. The results are in agreement to those reported by Najm et al. (2013), Ng'etich et al. (2013), Olaniyi and Ajibola (2008), Sincik et al. (2008), Honeycutt et al. (1996) and Greef (1994) that in average fresh and dry leaf yield of vegetables increases with increase in nitrogen fertilizer applied up to a point of stagnation and a decrease in dry matter production for nitrogen deficient soils. Lower growth and yield of plants fertilized with high urea rates may be associated with larger gaseous nitrogen losses (Kirchmann and Pettersson, 1995) or could be explained by the fact that a high concentration of soluble $\mathrm{N}$ increases the osmotic potential of the soil solution, causing reduction in water uptake by the plant roots.

when used at the optimal rate $\left(23.03\right.$ t.ha $\left.^{-1}\right)$, and can be used as a promising fertilizer source in Corchorus olitorius production in Benin. The findings opened a way for organic production of Corchorus olitorius.

services officer (named CPV/CeCPA Parakou). We are particularly indebted to the anonymous reviewers of this paper for their suggestions and constructive criticisms.

manure with NPK fertilizer on residual soil fertility, nutrient uptake and yield of maize. J. Agric. Res., 2: 191-197.

Agbede, T.M, Ojeniyi, S.O, Adeyemo, A.J., 2008. Effect of poultry manure on soil physical and chemical properties, growth and grain yield of sorghum in South western Nigeria. Ame-Eurasian J. Sustain. Agric., 2(1): $72-77$.

Alabadan B.A., Adeoye P.A., Folorunso E.A., 2009. Effect of different poultry wastes on physical, chemical and biological properties of soil. Caspian J. Environ. Sci., 7(1): 31-35.

Aliyu L. 2000. The effect of organic and mineral fertilizer on growth, yield and composition of pepper (Capsicum annum L). Biological Agriculture and Horticulture, 18: 29-36.

AOAC. Association of Official Analytical Chemists. 1990. Official methods of analysis of the association of 
official analytical chemists. 16th ed. Gaithersburg (MD): AOAC International.

Arancon N.Q., Edwards C.A., Lee S., Byrne R., 2006. Effects of humic acids from vermicomposts on plant growth. Eur. J. Soil Biol., 42: 65-69.

Ayeni L. S., Adetunji M. T., Ojeniyi S. O., 2008. Comparative nutrient release from cocoa pod ash, poultry manure and NPK 20:10:10 fertilizer and their combinations - incubation study. Nigerian Journal of Soil Science, 18: 23-26.

Ayodélé O.J, Omotoso S.O, Akinrinsola C.O., 2006. Phosphorus fertilizer use in melon (Egussi) seed production: effects on yield, oil and protein content and nutrient composition. Agricultural Journal, 1 (4): 216-220.

Bhattacharyya R., Kundu S., Prakash V., Gupta H.S., 2008. Sustainability under combined application of mineral and organic fertilizers in a rain fed soybean-wheat system of the Indian Himalayas. Eur. J. Agron, 28 : 33-46.

Dansi A., Adjatin A., Adoukonou-Sagbadja H., Adomou A., Faladé V., Yedomonhan H., Akpagana K., de Foucault B., 2009. Traditional leafy vegetables in Benin: Folk nomenclature, species under threat and domestication. Acta Botanica Gallica, 156,183-199.

Dansi A., Adjatin A., Adoukonou-Sagbadja H., Faladé V., Yedomonhan H., Odou D., Dossou B., 2008a. Traditional leafy vegetables and their use in the Benin Republic. Genetic Resources and Crop Evolution, 55: 1239-1256.

Darzi M.T. and Haj Seyd Hadi M.R., 2012. Effects of organic manure and nitrogen fixing bacteria on some essential oil components of coriander (Coriandrum sativum). International Journal of Agriculture and Crop Sciences, 4(12): 787-792.

Dauda S.N., Aliyu L., Chiezey U.F., 2005. Effect of seedling age at transplant and poultry manure on fruit yield and nutrients of garden egg ( $S$. gilo L.) varieties. Journal of Tropical Science, 5 (2): 38-41.

Dikinya O. and Mufwanzala N., 2010. Chicken manureenhanced soil fertility and productivity: Effects of application rates. Journal of Soil Science and Environmental Management, 1(3): 46-54.

Durbin J. and Watson G.S., 1950. "Testing for Serial Correlation in Least Squares Regression, I". Biometrika, 37 (3-4): 409-428.

El-Desuki M., Amer A.H., Sawan O.M., Khattab M.E., 2001. Effect of irrigation and organic fertilization on the growth, bulb yield and quality of sweet fennel under shark El-owinat conditions. J. Agric. Sci. Mansura Univ, 26 (7): 4465-4481.

Emuh F. N., 2013. Growth and yield performance of Corchorus olitorious $L$. influenced by levels of poultry manure in Niger-Delta, Nigeria. African Journal of Biotechnology, 12(19): 2575-2580.

Fujimoto T., 1998. Current Status of Soil Fertility in Nepal. Soil Science Program at a Glance. Annual Report. Soil Testing and Service Section. Ministry of Agriculture and Cooperatives. Government of Nepal, pp. 26-28.

Gensch R., Miso A., Itchon G., 2011. Urine as Liquid Fertilizer in Agricultural Production in Philipines: A Practical Guide. Xavier University Press, Philippines.

Greef J.M., 1994. Productivity of maize (Zea mays L.) in relation to morphological and physiological characteristics under varying amounts of nitrogen supply. Journal of Agronomy and Crop Science, 172: 317 - 326.

Grubben G.J.H. and Denton O.A., 2004. Plant Resources of Tropical Africa 2: Vegetables, PROTA Foundation, Wageningen, Netherlands/Backhuys Publishers, Leiden, Netherlands/CTA, Wageningen, Netherlands.

Harborne J.B., Baxter H., Moss G.P., 1999. Phytochemical Dictionary: A Handbook of Bioactive Compounds from Plants, 2nd edition, Taylor and Francis, Philadelphia, USA;

Herrera E., Tremblay N., Desroches B., Gosselin A., 1997. Optimization of substrate and nutrient solution for organic cultivation of medicinal transplants in multicell flats. J. Herbs Med. Plants, 4 (4): 69-82.

Honeycutt C., Clapham W., Leach S., 1996. Crop rotation and $\mathrm{N}$ fertilization effects on growth, yield, and disease incidence in potato. American Journal of Potato Research, 73(2): 45-61.

Jasso-Chaverria C., Hochmuth G.J., Hochmuth R.C., Sargent S.A., 2005. Fruit yield, size, and colour responses of two Greenhouse cucumber types to nitrogen fertilization in perlite soilless culture. Horticulture Technology, 15 (3): 565-571.

Khalil M.Y. and El-Sherbeny S.E., 2003. Improving the productivity of three Mentha species recently cultivated under Egyptian condition. Egypt. J. Appl. Sci., 18 (1): 285-300.

Khalil M.Y., Naguib Y.N., El-Sherbeny S.E., 2002. Effect of Tagetes erecta L. to some foliar application under compost levels. Arab Univ. J. Agric. Sci.,10 (3): 939964. 
Kirchmann H., Pettersson S., 1995. Human urine chemical composition and fertilizer use efficiency. Fert. Res., 40: 149-154.

Mbah C. N., 2006. Influence of organic wastes on plant growth parameters and nutrient uptake by maize (Zea mays L.). Nigeria J. Soil Sci., 16: 104-108.

Najm A.A., Hadi M.R.H.S., Fazeli F., Darz M.T., Rahi, A., 2012. Effect of Integrated Management of Nitrogen Fertilizer and Cattle Manure on the Leaf Chlorophyll, Yield, and Tuber Glycoalkaloids of Agria Potato. Communications in Soil Science and Plant Analysis, 43(6): 912923.

Najm A.A., Hadi M.R.H.S., Fazeli F., Darzi M.T., Fazeli $F ., 2013$. Influence of nitrogen fertilizer and cattle manure on the vegetative growth and tuber production of potato. Intl J Agri Crop Sci., 5 (2): 147-154.

Ng'etich O.K., Niyokuri A.N., Rono J.J., Fashaho A., Ogwen J.O., 2013. Effect of different rates of nitrogen fertilizer on the growth and yield of zucchini (Cucurbita pepo cv. Diamant L.) Hybrid F1 in Rwandan high altitude Zone. Intl J Agri Crop Sci., 5 (1): 54-62.

Ngeze P.B., 1998. Learn how to make and use compost manure in farming. Friend-of the-Book Foundation, Nairobi, Kenya. $45 \mathrm{Pp}$.

Njoku C. and Mbah C.N., 2012. Effect of burnt and unburnt rice husk dust on maize yield and soil physico-chemical properties of an ultisol in Nigeria. International Journal for Sustainable Production Systems, 28(1): 49-60.

O'Brien T.A. and Barker A.V., 1996. Growth of peppermint in compost. J. Herbs, Spices Med. Plant, 4 (1): 19-27.

Ogunrinde A.T. and Fasinmirin J.T., 2011. Soil Moisture Distribution Pattern and Yield of Jute Mallow (Corchorus olitorius L.) under Three Different Soil Fertility Management. Proceedings of the Environmental Management Conference, Federal University of Agriculture, Abeokuta, Nigeria, 2011.

Okonwu K. and Mensah S.I., 2012. Studies on soil amended with poultry manure and its effects on yield and yield components of pumpkin. Scientia Africana, 11 (1): 84-91.
Olaniyi J.O and Ajibola A.T., 2008. Growth and Yield Performance of Corchorus olitorius Varieties as Affected by Nitrogen and Phosphorus Fertilizers Application. American-Eurasian Journal of Sustainable Agriculture, 2(3): 234-241.

R Development Core Team, 2011. R: A Language and Environment for Statistical Computing. Copyright (C) 2011. The R Foundation for Statistical Computing, Vienna, Austria, ISBN 3-900051-070, http://www.Rproject.org.

Rekha CR. and Gopalakrishnan J.R., 2001. Effect of levels and frequencies of organic manures and inorganic fertilizers on growth and productivity of bitter gourd (Mamordica charantia L.). South Indian Horticulture, 49: 137-139.

Shapiro S.S. and Wilk M.B., 1965. An analysis of variance test for normality (complete samples). Biometrika, 52 (3-4): 591-611.

Sincik M., Turan Z.M., Göksoy A.T. 2008. Responses of potato (Solanum tuberosum L.) to green manure cover crops and nitrogen fertilization rates. American Journal of Potato Research, 85: 150158.

Snedecor G.W. and Cochran W.G., 1956. Statistical methods applied to experiments in agriculture and biology. The lowa State College Press, Ames.

Sridevi G. and Srinivasamurthy C.A., 2010. Utilization of human urine as a supplement to fertilizers in maize production. Madras Agric. J., 97 (7-9): 261-264.

Stewart E.A., Grimshaw H.M., Parkinson J.A., Quarmby C., 1974. Chemical analysis of ecological materials. Oxford: Blackwell Scientific Publications.

Sutagundi R.B., 2000. Effect of mulches and nutrient management on growth and yield of chilli (Capsicum annuum L.). M.Sc. (Agri.) Thesis, University of Agricultural Sciences, Dharwad.

Tisdale S.L. and Nelson W.L., 1990. Soil fertility and effect of magnesium sources on the yield and chemical composition of crops. Michigan Agric. Experimental Sta. Bull Press, Michigan American. 29-31. 